\title{
FIRE RISK CALCULATION IN SERRA DO CABRAL AT SIMÃO DIAS-SE, BRAZIL, USING THE ANGSTROM INDEX
}

\author{
FABIO WENDELL GRAÇA NUNES, RICARDO MONTEIRO ROCHA, JOSÉ ESPINOLA JR, \\ JOÃO HIGOR MENEZES DE SOUZA, MARCOS VENICIUS CARVALHO AMARAL, \\ JEAN HENRIQUE MENEZES NASCIMENTO \& IGOR DO NASCIMENTO SANTOS \\ Federal Institute of Education, Science and Technology of Sergipe, Brazil
}

\begin{abstract}
The forest fire prediction indexes are statistical tools used to assess the probability of fire occurrence, based on the weather conditions of the day or a time series. These indexes express whether there are favorable conditions for the occurrence of fire, which allows the adoption of more economic and effective preventive measures as well as the control over the planning of possible fires. The general objective of this research was to analyze if the atmospheric conditions are favorable to the occurrence of fires in Serra do Cabral in the municipality of Simão Dias - SE. According to White (2010), the most effective fire risk index to be applied in the territory of Sergipe is the Angstrom index. This index is based mainly on the temperature and the relative humidity of the air, both measured daily at $1 \mathrm{pm}$, being a non-cumulative index. Thus, this index was used to carry out the calculations of fire risk of the research. So atmospheric data were collected over a period of 4 years (2012-2015) and through this index, the fire occurrence conditions were determined. According to the results, the percentage of days with risk and the most favorable months of the fires were determined.
\end{abstract}

Keywords: atmospheric conditions, fire, risk index, forecast.

\section{INTRODUCTION}

Forest fires are one of the serious problems affecting the Brazilian fauna and flora, but also other countries with tropical and temperate climate, like the United States, Australia, African and Asian countries. In Brazil, the vast majority of fires are caused by man searching for economic purposes, misusing natural resources and contributing to environmental unsustainability.

Forest fire is the occurrence of fire out of control in any type of vegetation; it is often caused by fires that have not been duly authorized, toughened and monitored [1]. Forest fire is like a burning out of control that propagates consuming natural fuels of a forest, having as a main feature the fact that it propagates freely, responding only to changes of the environment and to the influences derived from plant-based fuels, climate and topography [2]. The burnings are agropastoral management procedures, in which the fire is used to clean the area for cultivation or for the burning of production remains, with the causative agent being man.

The record of forest fires is fundamental to know the problem that such phenomenon causes in a native or planted forest, not rarely ignored in its fullness. It is essential to know where, when and why these fires occur because, when you know the causes, we can establish an effective means to prevent or minimize its consequences [3].

In general, it can be said that man is the main cause of forest fires because most of them are initiated by some type of human activity. There are also fires caused by natural phenomena, but they are minimal. The most frequent causes of forest fires are: agropastoral practices, fires in areas of public visitation, intentional fires, smokers, electric lines, railroads, electric shocks (natural cause) and fishermen [4].

Forest fires are one of the most important factors in the reduction of forests and forests in the world, resulting in: destruction of vegetation cover, destruction of humus and death of 
microorganisms, destruction of wildlife, increase of pests in the environment, elimination of Seeds in a state of latency, nutrient loss and soil erosion [4].

The forest fire prediction indexes are statistical tools used to assess the probability of occurrence of fire, based on the weather conditions of the day or a time series [2]. These indexes expressing whether there are favorable conditions for its occurrence. Among the various utilities and applications of fire indexes, we can highlight: knowledge of the degree of risk, planning of fire control, permission to burn, among others. There are several fire hazard indexes in the literature, among them: Angstrom, Telicyn, Rodriguez and Moretti, Monte Alegre Formula and Monte Alegre Alterada.

The study area known as Serra do Cabral has beauty and historical value for the region. It is said that when Virgulino Ferreira da Silva, also known as Lampião (1898-1938), ran the northeastern states, doing justice with his own hands, he reached the Serra do Cabral to attack the city, however, the people of Simão Dias reacted, positioning themselves by the doors of their houses, causing Lampião to give up invading the city. However, the king of cangaço (highwayman) did not accept the withdrawal of invading the city for fear of the residents and found an honorable "excuse", saying that in respect to Our Lady of Santana, who is her godmother and the patron of Simão Dias, he would not invade the headquarters of the municipality. Today Serra do Cabral is better known as Serra do Cruzeiro, with potential for ecotourism, where visitors find a very famous restaurant in the city, a charming square and enjoy a panoramic view of the city.

Around the mountain, part of it is used as grazing for extensive livestock farming or planting grains like corn and beans. However, farmers use fires or coivaras technique, which constitutes of burning dry vegetation for the preparation of the soil, which can result in the loss of control of the situation enabling the spread of fire. Thus was the 2009 fire started: a farmer put fire in the pasture of a farm and strong winds in the area caused a major fire.

The objective of this work was to analyze if the climatic conditions are favorable for the occurrence of fires in Serra do Cabral in the municipality of Simão Dias-SE through calculations using the Angstrom Index. In addition, the elaboration of data that indicate the most favorable months to fires, enabling the adoption of more effective and economic preventive measures.

This study was carried out by high school students of the Federal Institute of Sergipe as a scientific initiation project of the IFS / PETROBRAS Agreement.

\section{MATERIAL AND METHODS}

The area of this study was Serra do Cabral in the municipality of Simão Dias - SE. The reasons to choose this area were given by the 2009 and 2012 fires, in this place of great potential for ecotourism and preservation of local flora and fauna, contributing to the progressive sustainability of the region.

The municipality of Simão Dias is located in the extreme west of the State of Sergipe, being limited to the north with the municipalities of Pinhão and Pedra Mole, to the east with Macambira and Lagarto, to the south with Riachão do Dantas and Lagarto and to the west with Tobias Barreto , Poço Verde and the State of Bahia. The municipal area covers $560.8 \mathrm{~km}^{2}$. The municipality has an altitude of 250 meters and geographic coordinates of $10^{\circ} 44^{\prime} 20^{\prime \prime}$ south latitude and $37^{\circ} 48^{\prime} 36^{\prime \prime}$ west longitude, at a distance of $100 \mathrm{~km}$ from Sergipe capital, Aracaju. With 40,199 inhabitants, estimated by the Brazilian Institute of Geography and Statistics (IBGE) in 2013. Its climate is dry and sub-humid tropical. The region is located in the Poligono das Secas, with an annual average temperature of $24.1^{\circ} \mathrm{C}$, but in winter the temperature can vary between $9^{\circ} \mathrm{C}$ and $18^{\circ} \mathrm{C}$. An interesting fact is that Simão Dias is the coldest city in Sergipe. Average rainfall per year is $880 \mathrm{~mm}$, more prevalent from March 
to August (autumn-winter). The municipal relief is represented by pediplanos with occasional tabular forms and crests, the city has many caves. The vegetation of the municipality comprises capoeira, caatinga, clean and dirty fields and vestiges of rainforest, it is also denominated of Northeastern Agreste. The city is inserted in the basins of the Vaza-Barris River and Piauí river, and as major rivers across the river Vaza-Barris, rivers Jacaré and Caiçá. The studied mountain is at an altitude of $424 \mathrm{~m}, 9 \mathrm{~km}$ from the center of the municipality. Fig. 1 is a view of the studied area in the city of Simão Dias and Figs. 2-4 show a fire occurred in Serra do Cabral on February 2012.

The meteorological data such as: air temperature, relative air humidity, corresponding to the studied periods, were collected on the INPE website (National Institute of Space Research) through its SINDA platform (Integrated Environmental Data System), which is located in Frei Paulo-SE, about $50 \mathrm{~km}$ from Serra do Cabral. There is a PCD [5] of the SINDA closest to the mountain, located in the municipality itself, Simão Dias, but the platform did not generate all the necessary data for the research, so the Frei Paulo platform was used, since it is the second closest to the mountain and generates all the necessary data. The period used for the collection of data was motivated by the fire occurred on $02 / 16 / 2012$. It was adopted for the study the period between January 2012 and August 2016.

According to Ribeiro and White [6], the most effective fire risk index to be applied in the territory of Sergipe is the Angstrom index. Thus, it was used to perform fire risk calculations within Serra do Cabral - SE.

The Angstrom index was developed in Sweden. This index is mainly based on the temperature and relative air humidity, both measured daily at $13 \mathrm{~h}$. It is a non-cumulative index and its equation is as follows:

$$
B=0.05 H \times\left(\frac{T-27}{10}\right),
$$

where:

$B=$ Angstrom index

$H=$ relative air humidity in $\%$

$T=$ air temperature in ${ }^{\circ} \mathrm{C}$

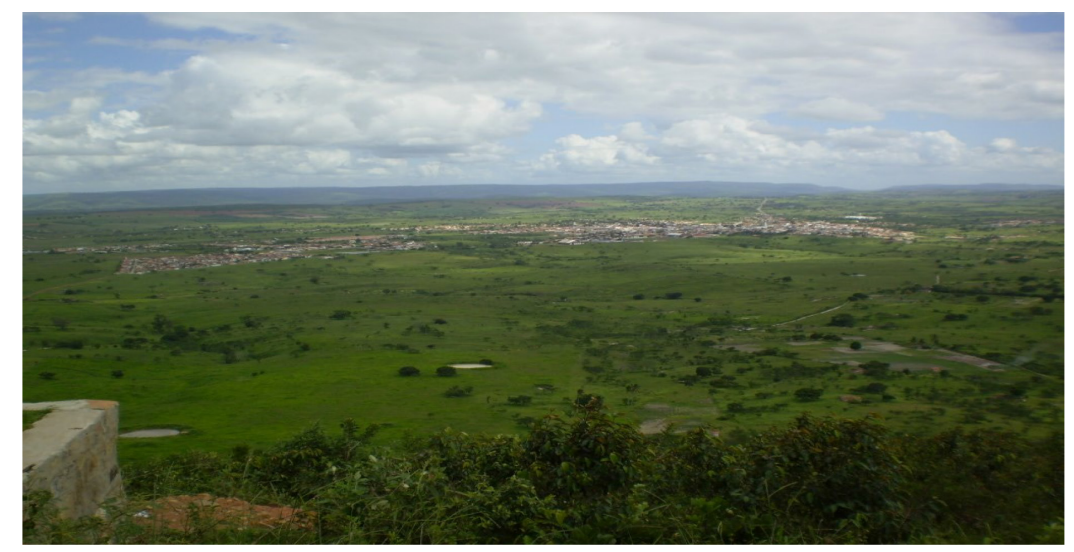

Figure 1: View of Serra do Cabral, with the city of Simão Dias in front. (Source: Alexandre Santos, 2007 [7].) 


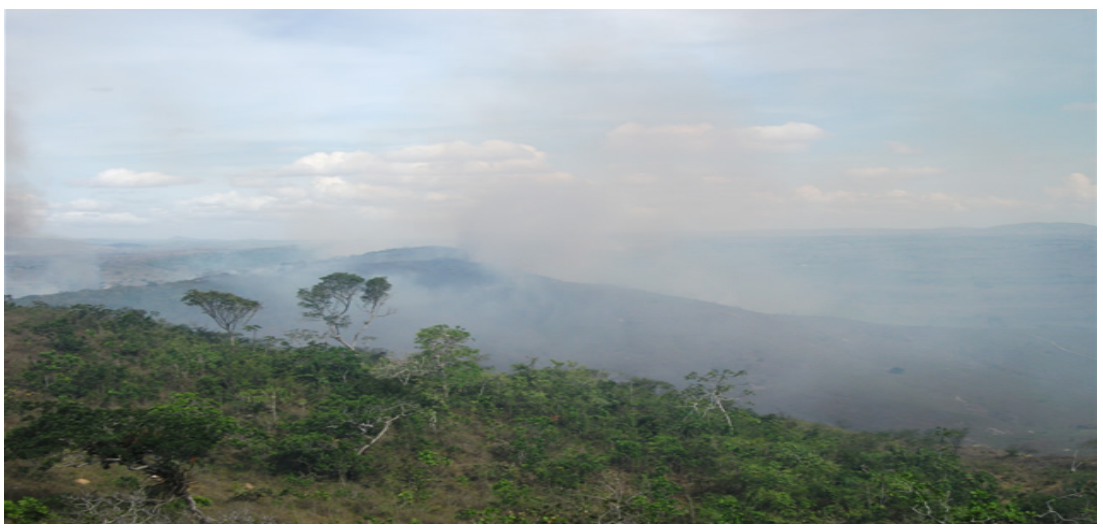

Figure 2: Fire in Serra do Cabral in February 2012. (Source: Denilson Matos / Portal Edelson Freitas, 2012 [8].)

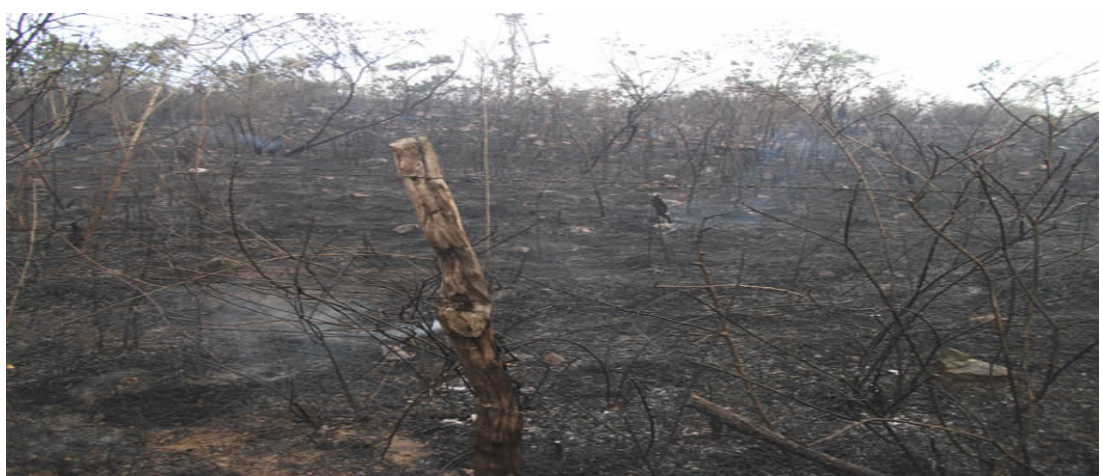

Figure 3: Fire in Serra do Cabral in February 2012. (Source: Denilson Matos / Portal Edelson Freitas, 2012 [8].)

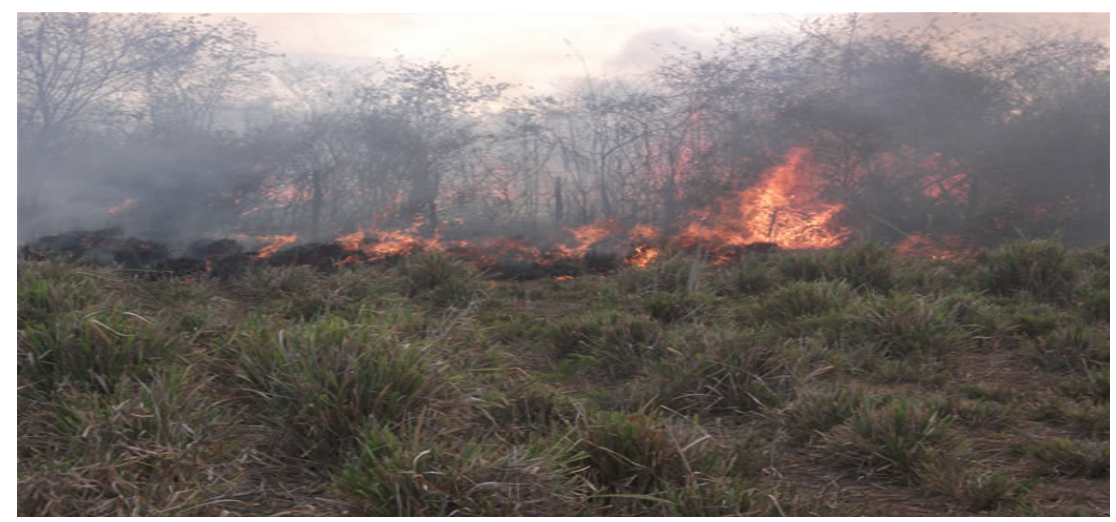

Figure 4: Fire in Serra do Cabral in February 2012. (Source: Denilson Matos / Portal Edelson Freitas, 2012 [8].) 
From the value obtained in the index can be determined the degree of fire risk, and when $\mathrm{B}$ is less than 2.5 there will be a fire hazard, that is, the weather conditions of the day will be favorable to the occurrence of fires. This index is not cumulative because it determines the degree of forest fire hazard only for a given day, without considering the weather conditions of the previous days.

\section{RESULTS AND DISCUSSION}

The chart below shows the historical series between January 2012 to August 2016 of the values of Angstrom index (Fig. 5), where values below 2.5 represent days with danger of fire occurrence.

Reinforcing the above results, a graph was created (Fig. 6) with the percentage of days in which there was risk and that there was no risk within the studied period. It is shown that on most days, Serra do Cabral did not provide favorable conditions for the occurrence of fires.

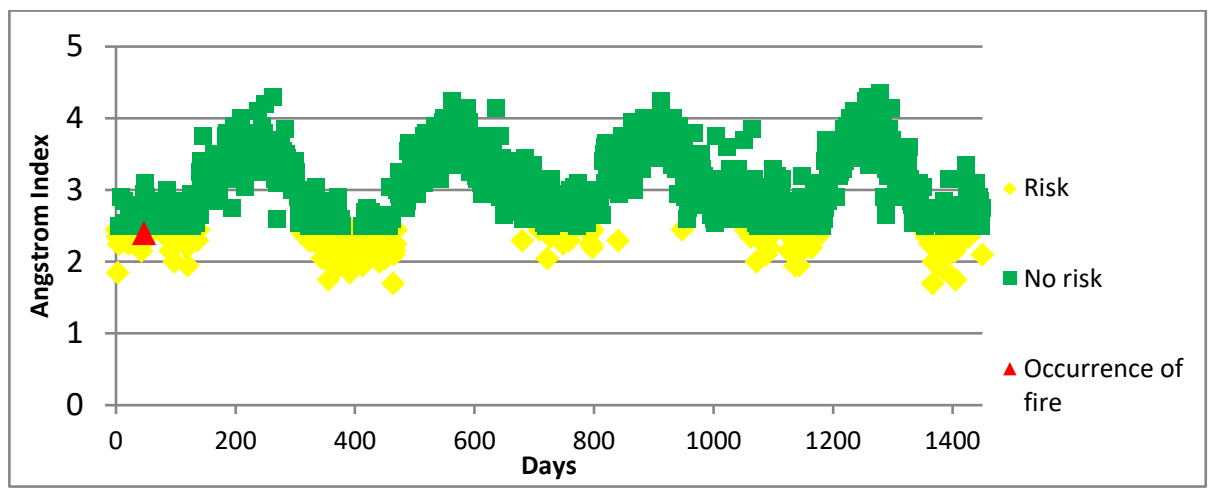

Figure 5: Historical series between January 2012 to August 2016 of the Angstrom Index values.

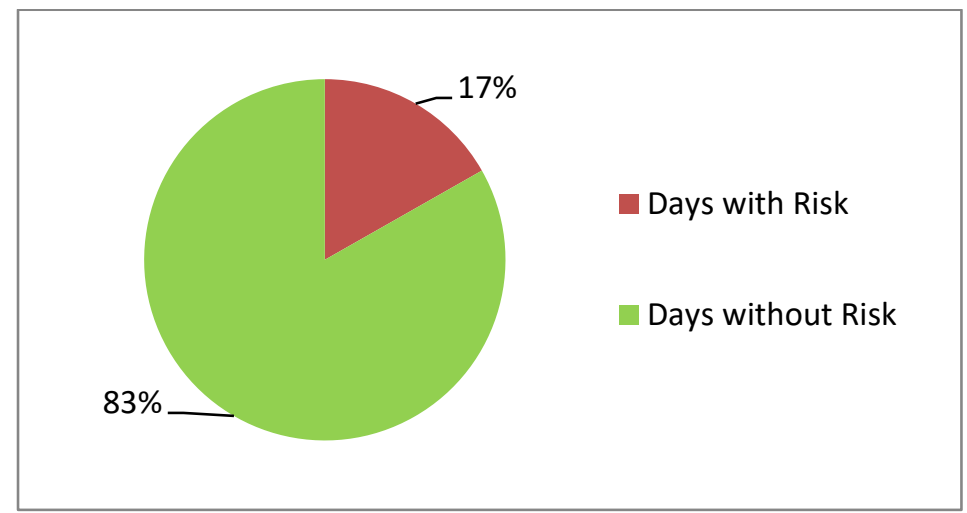

Figure 6: Graph showing the percentage of risk and risk-free days in the period between January 2012 and August 2016. 
Based on the data obtained, the graph below was made (Fig. 7), in which the percentage of days of the month with fire risk was determined. In this analysis, the month with the highest percentage of days with fire risk was that of February 2013. This month presented $92.9 \%$ of the days with fire risk.

Table 1 represents the average percentage of days in the month with fire risk in the four years of study.

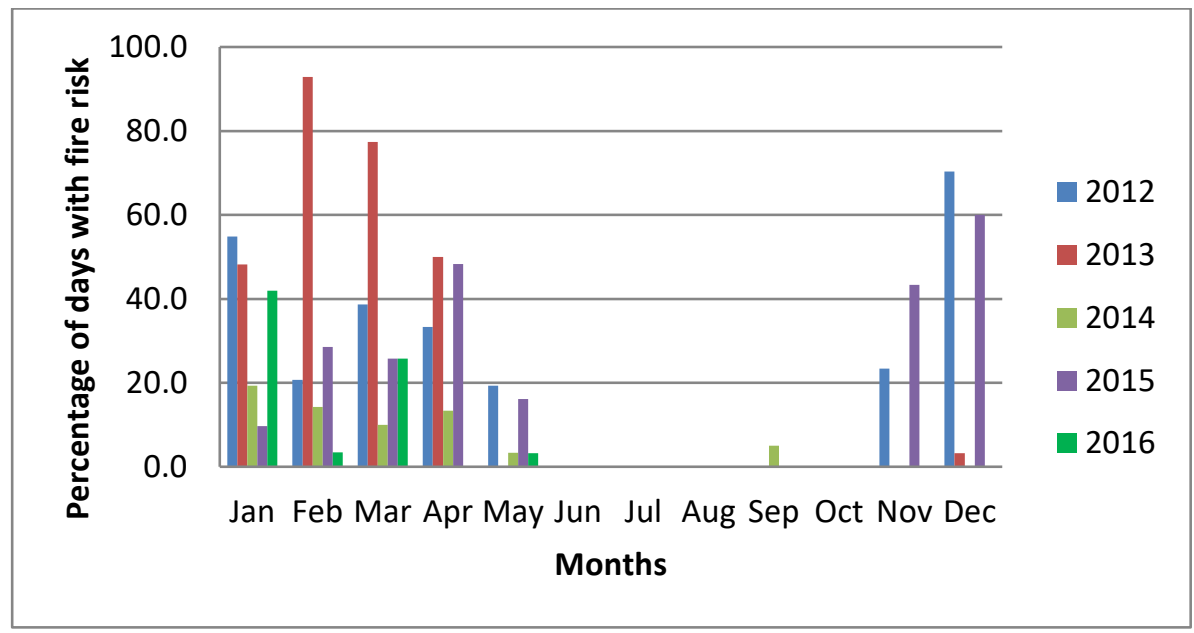

Figure 7: Graph with percentage of days with fire risk per month.

Table 1: Average percentage of days at risk of fire between 2012 and 2016.

\begin{tabular}{|l|l|}
\hline Month & $\begin{array}{l}\text { Average percentage of days with } \\
\text { fire risk (\%) }\end{array}$ \\
\hline January & 34.8 \\
\hline February & 32 \\
\hline March & 35.5 \\
\hline April & 29 \\
\hline May & 8.4 \\
\hline June & 0.0 \\
\hline July & 0.0 \\
\hline August & 0.0 \\
\hline September & 1 \\
\hline October & 0.0 \\
\hline November & 13.3 \\
\hline December & 26.7 \\
\hline
\end{tabular}




\section{CONCLUSIONS}

After analyzing the results it was identified the existence of $18 \%$ of the days of the year necessary conditions for the spread of fire in Serra do Cabral. It can also be concluded that the period between the months of December to April are the most favorable to the occurrence of fires. Thus, the fire hazard indexes are important, since the adoption of preventive measures can be planned and intensified in the period of greatest probability of occurrence of fires. It also became clear after the calculations that February is the most favorable month for fires, and the last two fires in the studied mountain were in February 2009 and 2012, which calls for more attention in that month of the year not only by responsible authorities but also by the population living around the mountain.

Fire hazard indexes prove to be a good tool for fire control planning measures. In order for the evaluation system of the degree of danger occurrence of forest fires in Serra do Cabral to be implemented, it is extremely necessary to set up a data collection platform within the Serra do Cabral area so that data can be obtained from local variables, thus being able to predict more efficiently the occurrence of fires damaging the fauna and flora.

\section{REFERENCES}

[1] IBAMA, Brazilian Institute of Environment and Renewable Natural Resources, Definition of Forest Fires, IBAMA. http://www.ibama.gov.br/phocadownload/ prevfogo/publicacoes/roteirometodologico.pdf. Accessed on: 5 Jun. 2016.

[2] Soares, R.V.\& Batista, A.C., Forest Fire: Control, Effects and Use of Fire, Curitiba, p. 264, 2007.

[3] Santos, J.F., Forest fire statistics in protected areas from 1998 to 2002.76 f. Dissertation (Masters in Forest Engineering), Agricultural Sciences Sector, Federal University of Paraná, Curitiba, 2004.

[4] Silva, R.G., Manual for Prevention and Combat of Forest Fires, Terra Brasilis. http://www.terrabrasilis.org.br/ecotecadigital/pdf/manual-de-prevencao-e-combateaos-incendios-florestais.pdf. Accessed on: 20 Jun. 2016.

[5] INPE (National Institute of Space Research), PCD's. SINDA - Integrated Environmental Data System. http://sinda.crn2.inpe.br/PCD/SITE/novo/site/index.php. Accessed on: 12 Jun. 2016.

[6] Ribeiro, A.S. \& White, B.L., Analysis of efficiency of forest fire occurrence hazard ratios for the Serra de Itabaiana National Park, Sergipe. Thinking About (Un) Sustainability: Challenge to Research, eds A.C. dos Santos, J.D. Filho, M.J. Soares \& P.C. Randow, Redes Editora: Porto Alegre, pp. 197-209, 2010.

[7] Santos, A., Simão Dias - View of the Serra do Cabral. http://www.panoramio.com/ photo/3019354. Accessed on: 2 Aug. 2016.

[8] Freitas, E., New fire in the tourist spot mountain! http://edelsonfreitas.com/portal/ noticias/vem-ai-bloco-pica-pau-2012-e-bloco-papa-leguas-em-sima-dias/. $\quad$ Accessed on: 2 Aug. 2016. 